\title{
O equívoco brasileiro: cotas raciais em concursos públicos*
}

\section{A Brazilian mistake: racial quotas for public employees}

\author{
Edilson Vitorelli Diniz Lima**
}

\section{RESUMO}

O presente artigo analisa a constitucionalidade das políticas de ação afirmativa, consistentes na criação de cotas para negros em concursos públicos, implementadas por estados federados e, mais recentemente, pela União, por intermédio da Lei no ${ }^{-12.990 / 2014}$. A partir da revisão da experiência norte-americana com políticas de ação afirmativa, dos precedentes relacionados com as cotas no ensino superior e da análise constitucional, conclui que as cotas, conquanto sejam constitucionais quando aplicadas ao ingresso de alunos no ensino superior, são formal e materialmente inconstitucionais quando inseridas em concursos públicos.

\section{PALAVRAS-CHAVE}

Direito constitucional - cotas-concursos públicos - inconstitucionalidade

* Artigo recebido em 19 de julho de 2015 e aprovado em 16 de agosto de 2015. DOI: http:// dx.doi.org/10.12660/rda.v271.2016.60768.

** Universidade Presbiteriana Mackenzie, Campinas, São Paulo, Brasil. E-mail: edilsonvitorelli@ gmail.com. Procurador da República. Doutor em direito pela Universidade Federal do Paraná, mestre pela Universidade Federal de Minas Gerais. Professor da Universidade Presbiteriana Mackenzie e da Escola Superior do Ministério Público da União. Visiting scholar na Stanford Law School e visiting researcher na Harvard Law School. 


\section{ABSTRACT}

This paper aims to analyze one of the many policies of affirmative actions in racial context, that have been introduce in Brazil in the last few years. A recently approved federal Statute, $\mathrm{n}^{-}$12.990/14, created quotas to black people in public contests designed to hire employees to work for the federal government. Adopting a comparative and analytical perspective, the research concludes that this kind of quotas violates the Brazilian Federal Constitution of 1988, although it is still possible to apply quotas in other fields of public policy that demand affirmative actions, specially in granting for black students access to public universities.

\section{KEYWORDS}

Quotas - public jobs - unconstitutionality

\section{Introdução}

Discutir relações raciais é um tabu. ${ }^{1}$ Nos Estados Unidos, onde tais relações são substancialmente piores que no Brasil, a expressão "to play the race card" se tornou simbólica do fato de que questões raciais não podem ser discutidas e sinônimo de se encerrar uma discussão fugindo de seu mérito. ${ }^{2}$ O evento jurídico usualmente mais referido como de uso indevido da "carta racial" ocorreu no final de 1991, quando Clarence Thomas, um advogado negro que recentemente havia sido nomeado circuit judge, foi indicado pelo presidente George Bush para a Suprema Corte. Ele substituiria Thurgood Marshall, o primeiro juiz negro que a havia integrado.

Em um evento quase cinematográfico, ${ }^{3}$ durante os procedimentos de apuração de vida pregressa do indicado, uma professora de direito graduada em Yale, Anita Hill, se apresentou dizendo que, no início da década de 1980, havia sido vítima de assédio sexual da parte de Thomas, quando ele era seu

1 Em sua concepção original, o tabu era algo ou alguém que havia caído em desgraça perante o grupo e, por essa razão, não poderia sequer ser tocado. Ver COULANGES, Fustel de. A cidade antiga. São Paulo: Martin Claret, 2002.

2 COLLIER, Peter; HOROWITZ, David. The Race Card: white guilt, black resentment, and the assault on Truth and Justice. Rocklin: Prima Publishing, 1997.

3 Evento este que, atualmente, foi retratado em filme, intitulado Anita, de 2013. 
empregador. Convocada para ser ouvida perante o Senado, o depoimento de Hill foi transmitido em rede nacional de televisão, incluindo descrições detalhadas das conversas de cunho sexual protagonizadas por Thomas, no ambiente de trabalho.

Hill não havia prestado queixa contemporaneamente aos fatos, mas alguns colegas de trabalho foram ouvidos, na mesma audiência, e confirmaram que ela lhes confidenciara, à época, que estava sendo assediada por Thomas. Um desses colegas foi perguntado se Hill era uma ativista, cuja intenção era usar a audiência para promoção pessoal ou da causa feminista. Esse colega respondeu: "Senador, eu sou um advogado de Wall Street. Comparado a Anita, eu sou um ativista". ${ }^{4}$

Thomas foi ouvido no dia seguinte. Uma de suas primeiras frases deixou antever a linha de seu depoimento: "issoé um linchamento em alta tecnologia". ${ }^{5}$ Se há 100 anos negros eram espancados e pendurados em árvores, Thomas reclamava para si, agora, a posição de vítima de um linchamento público televisivo. Nada disse quanto aos fatos, ou quanto às testemunhas. Limitouse a negá-los genericamente. Uma curiosidade, entretanto: Anita Hill, assim como todas as testemunhas ouvidas, também era negra.

Clarence Thomas foi confirmado no cargo, com uma votação de 52 contra 48. O Senado, de maioria republicana, considerou que nada estava provado que depusesse contra a imagem do indicado, que, até o presente, tem assento na Suprema Corte. O evento como um todo continua sendo debatido nos Estados Unidos e Anita Hill, que era professora de contratos - matéria, de fato, pouco afeita ao ativismo - , se tornou, segundo ela própria, contra sua vontade, um símbolo nacional da luta contra o assédio sexual. Verdadeiro ou falso, o caso Anita Hill demonstrou como é difícil conduzir uma discussão racional quando um dos elementos envolvidos é a questão racial.

O objetivo deste trabalho é se arriscar nesse terreno pantanoso, para demonstrar que o legislador federal, ao adotar a Lei no $12.990 / 2014$, se equivocou, em quatro frentes: primeiro, aplicou ao recrutamento de servidores públicos o parâmetro das ações afirmativas em universidades, desconhecendo que as situações são dissimilares; segundo, interpretou mal a experiência norte-americana em relação às políticas de ação afirmativa e discriminação no ambiente de trabalho; terceiro, se valeu de fundamentos estatísticos equivocados; e, quarto, violou formalmente a Constituição.

4 HILL, Anita. Speaking truth to power. Nova York: Anchor Books, 1997.

"This is a high-tech lich." 


\section{Existe preconceito racial no Brasil?}

A política racial brasileira é muito pautada pela experiência norteamericana. Isso é natural, considerando que o país é o mais avançado do continente, possui dimensões geográficas e populacionais similares e recebe, atualmente, um considerável número de estudiosos oriundos de outros países. Desde Joaquim Barbosa Gomes, ${ }^{6}$ vários autores que se dedicam ao estudo das relações raciais realizam estudos nos Estados Unidos.

Entretanto, não se deve superestimar a similaridade entre as relações raciais nos dois países. Conforme será demonstrado a seguir, há elementos estatísticos consistentes para sustentar a existência de preconceito racial no Brasil, distinto do preconceito relacionado com a classe social. Todavia, isso não significa que a situação seja idêntica à dos EUA. Um exemplo deve ser mantido em mente, na sequência da leitura. No estado do Alabama, a Constituição estadual exige referendo popular para sua alteração, antecedido por aprovação de 60\% do Legislativo. A Constituição, que é de 1901, ainda contém dispositivo determinando a segregação racial nas escolas, ineficaz há mais de 50 anos, em virtude da conhecida decisão da Suprema Corte em Brown v. Board of Education of Topeka. ${ }^{7}$ Em 2004, o Legislativo aprovou um referendo para, finalmente, retirar esse dispositivo da Constituição. Surpreendentemente, a iniciativa foi derrotada por 50,1\% dos eleitores, de modo que a segregação permaneceu inscrita na Constituição. Em 2012, novo referendo foi aprovado pelo Legislativo e votado pela população. Por incrível que possa parecer, uma maioria ainda mais maciça, 60,67\% dos eleitores, votou pela manutenção do texto, rejeitando a proposta do referendo. Isso faz com que se leia, na Seção 256, da vigente Constituição do estado do Alabama, a seguinte disposição: "Separate schools shall be provided for white and colored children, and no child of either race shall be permitted to attend a school of the other race". ${ }^{8}$ Seria inconcebível, no Brasil, em qualquer que fosse o momento histórico, ainda mais no presente, que a opinião pública majoritária

6 A obra sobre ações afirmativas do ministro foi desenvolvida primordialmente sob o paradigma norte-americano. Ver GOMES, Joaquim Barbosa. Ação afirmativa e princípio constitucional da igualdade. Rio de Janeiro: Renovar, 2001.

7 O advogado responsável pelo caso foi justamente Thurgood Marshall, que depois viria a ser, conforme mencionado, o primeiro juiz negro na Suprema Corte.

8 "Escolas separadas devem ser disponibilizadas a crianças brancas e negras, e nenhuma criança será autorizada a frequentar a escola da outra raça." 
defendesse, em qualquer estado, a construção de escolas públicas separadas para brancos e negros. Dizer que existe preconceito racial no país, portanto, não significa dizer que a situação é similar à norte-americana. Ela é distinta e o distanciamento precisa ser considerado.

Feita essa ressalva, cabe considerar, do lado oposto, se ela significa a inexistência de preconceito racial no Brasil. A tese da "democracia racial", tradicionalmente associada a Gilberto Freyre, ${ }^{9}$ foi contestada, ainda nas décadas de 1960 e 1970, por vários autores, tais como Florestan Fernandes e Carlos Hasenbalg, com a obra Discriminação e desigualdades raciais no Brasil, escrita como tese de doutoramento do autor no início da década de 1970 e publicado em 1979. ${ }^{10}$ Mais recentemente, Carlos Antonio Costa Ribeiro ${ }^{11}$ confirmou parcialmente as conclusões de Hasenbalg, sustentando, por um lado, que "as chances de mobilidade ascendente de pessoas com origens nas classes mais baixas são inteiramente determinadas pela origem de classe e a cor da pele não tem relevância", mas, por outro, que "as chances de mobilidade descendente e de imobilidade de pessoas com origens em classes mais altas [profissionais e trabalhadores não manuais de rotina] são significativamente influenciadas pela cor da pele". ${ }^{12}$

Essas análises permitem concluir que, mesmo que haja dúvidas sobre as situações de preconceito racial no Brasil, e que as pesquisas estatísticas ainda sejam deficientes, há elementos consistentes para se afirmar que uma pessoa negra tem menor acesso aos bens sociais no país, o que justifica, a priori, que medidas sejam adotadas para garantir essa igualdade.

9 Na verdade, embora Gilberto Freyre tenha celebrizado a expressão, Antonio Sérgio Alfredo Guimarães encontra referências anteriores a ela, que são expostas em Democracia racial. Disponível em: <www.fflch.usp.br/sociologia/asag/Democracia\%20racial.pdf>. Acesso em: 15 ago. 2011. Cabe observar que há algumas dubiedades na adoção da expressão por Freyre. O termo "democracia racial" nunca foi utilizado em suas obras principais e, mesmo nas obras secundárias em que aparece, é, por vezes, utilizado no sentido de uma pretensão, um porvir, e em outras como uma realidade já existente. Ver CRUZ, Levy. Democracia racial, uma hipótese. Disponível em: <www.fundaj.gov.br/tpd/128.html>. Acesso em: 15 ago. 2011. Ver, ainda, GUIMARÃES, Antonio Sérgio Alfredo. Democracia racial. Disponível em: <www.fflch.usp.br/ sociologia/asag/Democracia\%20racial.pdf>. Acesso em: 15 ago. 2011.

10 HASENBALG, Carlos. Discriminação e desigualdades raciais no Brasil. 2. ed. Belo Horizonte: Editora UFMG; Rio de Janeiro: Iuperj, 2005. A posição de Hasenbalg é exposta com mais detalhes em VITORELLI, Edilson. Estatuto da igualdade racial e comunidades quilombolas. 2. ed. Salvador: Juspodivm, 2015.

11 Classe, raça e mobilidade social no Brasil. Dados - Revista de Ciências Sociais, Rio de Janeiro, v. 49, n. 4, p. 833-876, 2006

12 Ibid., p. 855. 


\section{A constitucionalidade das ações afirmativas no ensino superior: as perguntas que ficaram sem resposta}

A conclusão do tópico anterior foi sufragada pelo Supremo Tribunal Federal, ao julgar a Ação de Descumprimento de Preceito Fundamental $186,{ }^{13}$ considerando constitucionais as ações afirmativas, por intermédio de reserva de vagas (cotas), nas universidades públicas. Essas ações constituem manifestação do princípio da igualdade em sentido substancial, visando desigualar, de modo benéfico, aqueles que concretamente estão em situação pior. ${ }^{14}$ Não há, nesse particular, nada de muito diferente do que Celso Antônio Bandeira de Mello apontou, ainda no final da década de 1970, quando tratava do conteúdo jurídico do princípio da igualdade. ${ }^{15} \mathrm{~A}$ polêmica relacionada com as ações afirmativas é, certamente, muito mais ideológica que jurídica. Como disse Lyndon Johnson, presidente dos Estados Unidos, em 1965, "você não pega uma pessoa que foi tolhida por correntes e a liberta, a põe na linha de partida de uma corrida e então diz - 'você está livre para competir com os

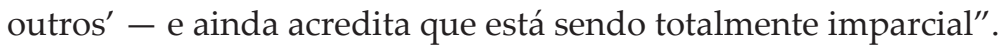

Aceitar a constitucionalidade das ações afirmativas no ensino superior, portanto, é decidir um caso relativamente fácil. Incide o princípio da igualdade, há fundamentos estatísticos que mostram a desigualdade fática decorrente da raça e, acima de tudo, não há óbice constitucional em outras normas. A Constituição não determina que o ensino superior público e gratuito deva ser dispensado por critérios de mérito. É certo que o art. 208, V, estabelece o "acesso aos níveis mais elevados do ensino, da pesquisa e da criação artística, segundo a capacidade de cada um", mas isso significa apenas o reconhecimento de que os níveis mais elevados de ensino, pesquisa e criação artística não são oferecidos a todos, diferentemente da educação fundamental, disciplinada nos incisos anteriores. Não há direito de acesso universal a esses níveis elevados, que dependerão do pendor e da capacidade do interessado para enfrentar as dificuldades que lhe são inerentes. Contudo, a Constituição não exigiu que um exame seja a única forma de se avaliar a capacidade ou o

13 Embora julgada em abril de 2012, o acórdão da ADPF, mais de dois anos depois, quando as presentes linhas foram escritas, ainda não havia sido publicado.

14 SARMENTO, Daniel. Direito constitucional e igualdade étnico-racial. In PIOVESAN, Flávia; MARTINS DE SOUZA, Douglas. Ordem jurídica e igualdade étnico-racial. Rio de Janeiro: Lumen Juris, 2008. p. 78.

15 BANDEIRA DE MELLO, Celso Antônio. O conteúdo jurídico do princípio da igualdade. São Paulo: Malheiros, 2010. p. 41. 
potencial do candidato. A educação, como qualquer outra política pública, admite critérios variados de implementação, sendo o mérito do beneficiário apenas um deles. Em outras palavras, o exame vestibular não é uma cláusula constitucional.

\subsection{Quem são os negros?}

Nada disso significa que não houvesse questões difíceis na ADPF 186. Ocorre que elas foram evitadas pelo Supremo Tribunal Federal, segundo o que se tem notícia da minuta de voto divulgada pelo relator e das notas da sessão, e pela Procuradoria-Geral da República, por ocasião da emissão de seus pareceres no processo. A principal delas se refere à identificação dos beneficiários da política.

Não existe, como se sabe, um conceito biológico de raça. ${ }^{16} \mathrm{~A}$ raça foi inventada pelos povos europeus como forma de justificar a ocupação da África e da América e, posteriormente, incorporada por posições pseudocientíficas no século XIX e início do século XX. O fato de ser falso não significa, contudo, que o conceito seja irrelevante. Socialmente, ele desempenhou um papel histórico dificilmente igualado por outras noções abstratas. Poucas ideias causaram tantas mortes, na história da humanidade, quanto a raça. Entretanto, como o Brasil nunca teve, diferentemente dos Estados Unidos, políticas públicas de segregação racial posteriores à abolição da escravatura, nem proibições ao casamento inter-racial, ${ }^{17}$ a sociedade brasileira se constituiu em um contínuo de cores que alarga a zona de incerteza na definição de quem é negro.

Abstratamente, seria possível adotar dois critérios para essa definição: genotípico ou fenotípico. O critério genotípico, adotado por muitos anos, nos Estados Unidos, ${ }^{18}$ considera a herança genética vinculada a antepassados africanos. Será negro quem tiver essa ascendência. Essa possibilidade merece ser de pronto descartada, uma vez que preconceito racial no Brasil não deriva de qualquer consideração genealógica, mas sim dos traços físicos, pouco importando quão distante está o indivíduo de uma eventual origem africana.

16 BARBUJANI, Guido. A invenção das raças. São Paulo: Contexto, 2007. p. 156.

17 Nos Estados Unidos, apenas em 1967, no julgamento de Loving v. Virginia, a Suprema Corte declarou inconstitucionais leis estaduais que proibiam casamentos inter-raciais.

18 Essa solução foi aplicada nos Estados Unidos em Plessy v. Ferguson: Plessy foi considerado negro, apesar de ter apenas $1 / 8$ de ascendência africana e aparência mulata clara. 
Resta, então, apenas o critério fenotípico, que é a delimitação dos beneficiários a partir de suas características físicas. Aceitando-o, é patente que haverá uma zona de certeza positiva. Há pessoas que ninguém discordaria que são negras. Também haverá uma zona de certeza negativa, em relação às pessoas que não são negras. Entretanto, há uma imensa zona de incerteza, entre as pessoas que são mestiças ou miscigenadas, as quais o Instituto Brasileiro de Geografia e Estatística (IBGE) denomina pardas.

O problema é que a Lei no 12.990/2014, assim como o Estatuto da Igualdade Racial, definiram como negras as pessoas que são "pretas e pardas", de acordo com o IBGE. Logo, partindo das categorias do instituto, todos aqueles que não são indígenas, nem amarelos, nem brancos, são negros. Os pardos são negros para todos os efeitos, tanto quanto os pretos. Por essa razão, a população potencialmente beneficiária das ações afirmativas, no Brasil, equivale a $50,7 \%$ de todos os cidadãos do país, de acordo com o IBGE. Assim, na zona de incerteza estarão todas as pessoas que são, para utilizar uma expressão hoje em desuso, "morenas". Quem não tem as características fenotípicas da população branca é pardo, por isso, negro e potencial beneficiário das ações afirmativas. Para efeitos legais, não só os pretos são negros.

Isso dificulta a definição das características fenotípicas que seriam adequadas para que alguém fosse considerado negro. Qual tom de pele, qual formato de nariz ou da cabeça, textura de cabelo ou espessura dos lábios alguém tem que ostentar para poder ser considerado pardo ou preto e, assim, negro? Nenhuma das leis federais ou estaduais, já promulgadas no Brasil, adotando a raça como critério, para qualquer finalidade, definiu quais seriam esses traços. O legislador não soube como resolver o problema e, talvez, não tenha querido discutir um assunto tão delicado. As normas dizem apenas que negros são pretos e pardos, mas não dizem quem são os pretos e pardos, como se esses conceitos fossem tão certos quanto o local de nascimento do indivíduo. Com a grande miscigenação racial da população, é praticamente impossível saber quando alguém deixa de ser pardo e passa a ser branco.

O Supremo Tribunal Federal, na ADPF 186, passou ao largo desse problema. A ausência de parâmetro legal foi, por isso, complementada pela ausência de parâmetro jurisprudencial. O Brasil implementou políticas de ação afirmativas destinadas a uma população que nem a lei, nem os juízes estão dispostos a identificar. 


\subsection{A condição de negro é sindicável?}

Suponha-se, para fins de argumentação, que seja possível definir, dentro do critério fenotípico, quais são os traços físicos desejados, ou seja, quando alguém deixa de ser pardo para ser branco. Se isso for possível, passa a ser necessário decidir como esses traços serão verificados. Há, para tanto, dois parâmetros possíveis, quais sejam, a autodeclaração e o heterorreconhecimento.

A autodeclaração é o parâmetro adotado nos Estados Unidos e em todas as leis brasileiras que utilizaram a raça como elemento para a dispensação de ações afirmativas. $\mathrm{O}$ interessado apenas declara que se autoidentifica como negro, ou, dependendo da lei, como preto ou como pardo. Nada mais do que isso. A vantagem desse critério é que ele permite que se adie o desafio anterior, que é a definição "objetiva" de quem é negro. Se o indivíduo assim se julga, o Estado reconhecerá sua autonomia.

Todavia, o Brasil, nos passos de Portugal, é especialista em determinar a quadratura do círculo. ${ }^{19}$ À revelia da lei, órgãos e entidades públicas se arrogaram o direito de definir quem é negro no Brasil e, portanto, realizar um heterorreconhecimento racial, com o objetivo declarado de evitar fraudes. A pioneira na adoção da ideia infeliz e sem precedentes foi a Universidade de Brasília, por ocasião da adoção do sistema de cotas no vestibular. A UnB criou uma comissão cujos nomes dos integrantes não eram públicos, para julgar, com critérios igualmente secretos, se os postulantes a vagas, na condição de cotistas, eram ou não negros. Apenas no vestibular 2012, essa comissão eliminou aproximadamente 300 candidatos que haviam se declarado negros. Apesar de a decisão ser submetida a recurso, nem as razões de eliminação, nem de sua revisão foram publicadas. $\mathrm{O}$ edital também não trouxe critérios que pudessem orientar o candidato no sentido do que seria considerada uma declaração "verdadeira".

A ideia da UnB foi adotada pela Universidade Federal do Paraná e, posteriormente, pelo próprio estado do Paraná, o primeiro a criar cotas raciais em seus concursos públicos, por intermédio da Lei no $¹ 4.274$, de 2003 . Na

19 Essa expressão foi utilizada pelo professor José António de Avelãs Nunes, para descrever o julgado do Supremo Tribunal de Justiça, que decidiu que, embora esteja literalmente determinado na Constituição portuguesa que a saúde pública é gratuita, podem ser cobradas "taxas moderadoras", para impedir o uso abusivo do sistema. Até hoje, o mesmo tribunal não disse quando um uso começa a ser abusivo e a cobrança incide, indiscriminadamente, sobre todos os usuários. Ver NUNES, António José Avelãs; SCAFF, Fernando Facury. Os tribunais e o direito à saúde. Porto Alegre: Livraria do Advogado, 2011. 
UFPR, o eufemístico nome dado à comissão deixa claro o encaixe forçado de conceitos: "comissão de verificação da autodeclaração". Esse era o principal ponto controvertido da ADPF 186, evitado tanto pelos pareceres apresentados pela Procuradoria-Geral da República quanto peloSTF. A açãonão questionava propriamente a existência das cotas, mas do que enfaticamente denominava "tribunal racial" na Universidade de Brasília, havendo pedido expresso no sentido de que a política, caso validada, ficasse restrita ao parâmetro de autodeclaração. De fato, nesse ponto, a razão estava com o autor. É impossível pretender que alguém possa legitimamente se arvorar a autoridade de, no Brasil, dizer quem é negro. Nem nos Estados Unidos, onde a diferenciação racial é mais evidente, existe heteroverificação. Aceita-se, quando se trata de igualdade racial, que algum nível de fraude é um preço pequeno a se pagar, em comparação com o que seria a definição de "autoridades em raça", que pudessem classificar as pessoas. Assim os americanos fazem políticas raciais há quase 40 anos. "You just check the box".

Em seu voto, o ministro relator Ricardo Lewandowski aborda a questão da heteroverificação em menos de duas, das 47 páginas que o compõem, para concluir que "Tanto a autoidentificação, quanto a heteroidentificação, ou ambos os sistemas de seleção combinados, desde que observem, o tanto quanto possível, os critérios acima explicitados e jamais deixem de respeitar a dignidade pessoal dos candidatos, são, a meu ver, plenamente aceitáveis do ponto de vista constitucional".

Ocorre que não existem os "critérios acima explicitados". O trecho anterior do voto é quase todo dedicado a uma citação da obra de Daniela Ikawa, ${ }^{20}$ na qual a autora elenca meios de se fazer a heteroidentificação fotografias, entrevistas, declarações - e não critérios que devem orientá-la, ou qual expertise habilita alguém a exercer esse papel. Assim, para o STF, tanto autoidentificação quanto heterorreconhecimento são parâmetros válidos para se identificar alguém como negro, embora nem o Supremo Tribunal, e nem as obras acadêmicas digam como deve agir o avaliador.

\section{Sindicabilidade da condição de negro: decisões judiciais}

Quando as cotas em concursos públicos foram implantadas, ainda em 2003, no estado do Paraná, a Lei no 14.274/2003 determinou que o critério

20 IKAWA, Daniela. Ações afirmativas em universidades. Rio de Janeiro: Lumen Juris, 2008. p. 129. 
de habilitação à vaga deveria ser a autodeclaração do candidato. Previu, entretanto, que, no caso de declaração falsa, o candidato seria desclassificado. Em razão dessa previsão, o Poder Executivo paranaense se sentiu autorizado a criar comissões para avaliar a veracidade das declarações prestadas pelos candidatos. Algo similar ocorreu no estado do Mato Grosso do Sul, que adotou cotas em concursos públicos em 2008, por intermédio da Lei no 3.594. Embora a norma legal faça referência à autodeclaração, o Decreto no 13.141/2011, que a regulamentou, determinou a criação de uma comissão para, "mediante processo de entrevista, verificar a veracidade da declaração firmada pelo candidato" e "confrontá-la com o fenótipo do candidato".

Partindo do pressuposto de que a experiência paranaense é a mais antiga, realizou-se pesquisa no site do Tribunal de Justiça, no intuito de verificar a existência de conflitos judiciais relacionados com a criação das referidas comissões de verificação. Os resultados demonstraram que as comissões paranaenses vêm reprovando candidatos, os quais tentam, pela via jurisdicional, reverter as decisões. Em relação à existência das comissões de avaliação, com apoio em parecer da Procuradoria-Geral de Justiça, o TJPR asseverou:

É válida e até mesmo necessária a entrevista que se levou a efeito, imposta que foi a todos os candidatos, nada tendo de ilegal como bem ponderou a Douta Procuradoria-Geral de Justiça, verbis: “Com efeito, não se pode considerar como consequência natural da simples declaração de candidato que se autointitula afrodescendente, a obrigação de a Administração Pública reconhecer tal circunstância sem qualquer outra verificação adicional e, assim, quando aprovado em todas as fases do certame, de nomeá-lo ao exercício da função pública. Entendimento contrário, tal como sustentado pelo agente ministerial de primeiro grau, [...] ensejaria verdadeira descredibilidade no ente contratante, bem como, ocasionaria imenso abalo social na legislação afirmativa que instituiu o chamado sistema de cotas em concursos públicos". [...]

Há regras que não necessitam constar expressamente do documento que exterioriza o ato administrativo. Há coisas que a Administração e o administrado podem facilmente perceber e comportar-se de acordo com elas desde que atuem com lealdade (boa-fé objetiva). E a necessidade da averiguação da real ascendência dos candidatos é uma dessas coisas. [...] Aliás, assim não pudesse proceder a Administração Pública, ou seja, investigar a veracidade da declaração do candidato, a Lei $\mathrm{n}^{\mathrm{o}}$ 14.274/03 não teria nenhuma efetividade porque a reserva de 
vagas nos concursos públicos aos afrodescendentes seria "letra morta", já que simples a sua burla. A jurisdição com isso não pode compactuar. [TJPR - 4 $4^{\text {a }}$ C. Cível - ACR 0355072-7 - Foro Central da Região Metropolitana de Curitiba - rel.: des. Adalberto Jorge Xisto Pereira Unânime - J. 30.1.2007]

Ressalvadas as considerações de senso comum acerca do "imenso abalo social" que seria causado se a administração não verificasse a condição de negro de um candidato, porque isso transformaria a norma em "letra morta", todos os demais argumentos do voto são formais e, da perspectiva do direito administrativo, discutíveis. Afirma-se que não houve violação ao devido processo legal porque houve possibilidade de recurso, quando o argumento do requerente, relatado no próprio acórdão, não se relaciona à existência de mecanismos recursais, mas à subjetividade dos critérios utilizados. A possibilidade de recurso certamente não regulariza a falta de critério. $\mathrm{O}$ julgado ainda argumenta, de modo contraditório, que os princípios da lealdade e boa-fé objetiva exigem que a administração crie os mecanismos de verificação, ou seja, que desconfie do administrado. Em momento algum da decisão, o Tribunal diz se o candidato envolvido no conflito é ou não é negro, ou seja, se a decisão administrativa foi justa ou injusta.

Essa tendência é confirmada pela evidência de que apenas o concurso para o cargo de soldado da Polícia Militar do Paraná gerou cinco decisões do TJPR, nos últimos quatro anos, relacionadas a cotas raciais. ${ }^{21}$ Quatro delas foram embasadas em argumentos exclusivamente formais, como o respeito à ampla defesa e ao contraditório no âmbito administrativo e a atribuição de direito de recurso ao candidato. Também se afirma que "a demonstração do histórico racial do impetrante é questão que exigiria dilação probatória e, por tal razão, se revela incompatível com o rito do mandado de segurança". ${ }^{22}$ A mesma justificativa é aplicada "acerca da insurgência com relação aos critérios legais de avaliação (genotípico ou fenotípico): o mandado de segurança não é meio idôneo para afastar ofensa em tese, e não se presta para discutir as escolhas políticas concretizadas no texto da lei" ${ }^{23} \mathrm{Em}$ dois

\footnotetext{
21 São eles: Acórdão 6. 675962-8, rel. Rogério Ribas, DJ 4.10.2010; Acórdão 4. 843110-1, rel. Leonel Cunha, j. 27.3.12; Acórdão 3. 1004787-9, rel. Regina Afonso Portes, j. 9.7.13; Acórdão 2. 1074674-8, rel. Wellington Emanuel C de Moura, j. 23.1.14 e Acórdão 1. 1148891-8, rel. Coimbra de Moura, j. 11.11.14.

22 Acórdão 6. 675962-8, rel. Rogério Ribas, DJ 4.10.2010

23 Ibid.
} 
dos acórdãos, afirma-se expressamente que "Não cabe ao Poder Judiciário apreciar os critérios adotados pela subcomissão de avaliação para enquadrar um candidato como afrodescendente ou não, mas tão somente analisar a legalidade do ato administrativo" ${ }^{24}$

O Superior Tribunal de Justiça teve oportunidade de, em um caso, rever julgado oriundo do Tribunal de Justiça do Paraná e, em sua decisão, se ateve aos mesmos argumentos formais:

1. A atuação do Poder Judiciário em concursos públicos deve se restringir à verificação da observância dos princípios da legalidade e da vinculação ao edital, em razão da discricionariedade da Administração Pública. Precedentes do STJ.

2. In casu, ficou constatado pelo acórdão recorrido que não há direito líquido e certo a ser protegido, pois há obediência pela Banca Examinadora dos critérios de avaliação da condição de afrodescendente do candidato, previstos no edital do concurso, bem como dos princípios constitucionais da legalidade e da igualdade.

3. Agravo Regimental não provido.

[AgRg no RMS 33.654/PR, rel. ministro Herman Benjamin, julgado em 14/8/2012, DJe 27/8/2012]

A insistência em argumentos formais é incoerente com o entendimento do próprio Superior Tribunal de Justiça em praticamente todos os assuntos relacionados com concursos públicos. Nessa seara, a jurisprudência vem restringindo cada vez mais a liberdade do administrador, a ponto de se permitir, ainda que excepcionalmente, anular questões de múltipla escolha formuladas pela banca, apenas por não concordar com seu teor. ${ }^{25}$ Em relação às cotas destinadas a deficientes físicos, o Superior Tribunal de Justiça proferiu centenas de decisões para determinar quais deficiências são ou não suficientes para permitir que o candidato faça jus ao benefício. O grau de escrutínio das decisões administrativas, nesse caso, foi tão elevado que o STJ estabeleceu

24 Acórdão 3. 1004787-9, rel. Regina Afonso Portes, j. 9.7.13 e Acórdão 2. 1074674-8, rel. Wellington Emanuel C de Moura, j. 23.1.14.

25 Por exemplo, AgRg nos EDcl no AREsp 244.839/PE, rel. ministro Napoleão Nunes Maia Filho, julgado em 6/11/2014: “No caso em apreço, a questão 2 da Prova de Língua Portuguesa, Caderno 36, do Concurso da Polícia Rodoviária Federal, regulado pelo Edital 1/2009, está contaminada pelo vício de ilegalidade, que a macula de forma insofismável, tornando-se, assim, suscetível de invalidação na via judicial". 
que enxergar com apenas um olho é deficiência para fins de concurso, ${ }^{26}$ mas ouvir com apenas um ouvido, não. ${ }^{27}$ É claro que raça não é deficiência, mas a situação é em tudo análoga: um candidato pretende se valer de uma condição pessoal para obter condição mais favorecida em um concurso público. Não há fatores que distingam a situação racial, a fim de justificar que, apenas nesse caso, a administração possa adotar a conduta que julgar melhor, livre de revisão judicial, desde que respeite garantias processuais.

Há apenas um caso, entre os cinco pesquisados no TJPR, em que o relator, de fato, entra no mérito da questão, sendo esse o único em que a decisão da administração foi reformada e o candidato foi habilitado ao certame. Argumenta o desembargador Coimbra de Moura: ${ }^{28}$

Sob outro vértice, é possível ao Poder Judiciário analisar os fundamentos dos atos administrativos discricionários, a fim de averiguar não só a legalidade, mas também eventual violação aos princípios da razoabilidade e da proporcionalidade, sem que isso implique em afronta ao princípio da harmonia entre os poderes.

O controle judicial sobre os atos discricionários é justificável, em vista à necessidade de evitar o abuso de poder do administrador público, que deve ser submetido ao controle dos seus atos, seja em razão do princípio da inafastabilidade da jurisdição, seja para evitar arbitrariedades que, além de comprometerem o próprio Estado Democrático de Direito, ofendem direitos subjetivos.

Fixadas essas premissas, verifica-se que, na espécie, o ato administrativo objurgado ofende à razoabilidade e proporcionalidade, pois, conforme bem expôs a respeitável sentença, a fotografia acostada às fls. 19 revela que o impetrante é da cor parda, ao passo que sua família é da etnia negra, conforme certidões de nascimento (fls. 210/212) e demais fotografias (fls. 217-TJ e seguintes).

\footnotetext{
26 Súmula 377: “O portador de visão monocular tem direito de concorrer, em concurso público, às vagas reservadas aos deficientes".

27 "O acórdão recorrido foi proferido em sintonia com a atual jurisprudência do Superior Tribunal de Justiça, segundo a qual os portadores de deficiência auditiva unilateral não podem ser enquadrados como pessoas com deficiência (MS 18.966/DF, relator p/ acórdão o ministro Humberto Martins, Corte Especial, DJe 20/3/2014)". (AgRg no REsp 1379284/SE, rel. ministro Benedito Gonçalves, j. 18/11/2014).

28 Acórdão 1. 1148891-8, rel. Coimbra de Moura, j. 11.11.14.
} 
Tem-se daí que o ato coator é ilegal e viola direito líquido e certo, não restando alternativa senão negar provimento ao recurso.

Conforme fica visível, o relator não disse quais características fenotípicas o levaram a considerar o candidato pardo e, portanto, negro, mas ele tem o mérito inegável de não ter se valido de ressalvas processuais pouco convincentes para se esquivar da difícil decisão. Além disso, a transparência com a qual expôs o seu raciocínio é elogiável. O que fez foi olhar a foto de um candidato e dizer "esse sujeito é pardo". Exatamente como as comissões o fazem, embora disfarçadamente, por intermédio de procedimentos burocráticos.

O problema com essa decisão, todavia, é que ela apenas explica o procedimento utilizado pelo julgador na análise da prova dos autos, mas não o justifica. Como a fotografia do impetrante não faz parte do acórdão, é impossível submeter a decisão ao escrutínio público, exatamente da mesma forma que é impossível fazê-lo com as decisões administrativas. O que se faz é o que nos Estados Unidos já foi chamado de "snif test". Em síntese, o juiz não diz quem é negro, não justifica a decisão - afinal, seria politicamente incorreto - , mas, intimamente, ele sabe que, quando vir alguém que é negro, saberá que é. Ainda que isso possa parecer aceitável, trata-se de raciocínio que padece de severo defeito: a Constituição brasileira não é lacônica como a dos Estados Unidos e veda expressamente, no art. 93, IX, que decisões judiciais sejam adotadas por motivos de íntima convicção do julgador.

Nesses termos, se o Poder Judiciário deve dizer quem é negro, ele necessariamente deverá fazê-lo fundamentadamente. Não basta que o juiz olhe para a fotografia, ou para a pessoa de cada impetrante, e afirme ou negue essa conclusão. Da mesma forma, se a administração pública pretende dizer quem é ou não é negro, o primeiro requisito que deveria ser exigido é a motivação da decisão. Não basta, como pretendeu o TJPR, que a decisão seja unânime entre os membros da comissão, ou que tenha havido oportunidade de recurso. Conforme assevera Celso Antônio Bandeira de Mello, nas situações “em que existe discricionariedade administrativa ou em que a prática do ato vinculado depende de atirada apreciação e sopesamento dos fatos e das regras jurídicas em causa, é imprescindível motivação detalhada" ${ }^{29}$ Não pode haver tema administrativo que desperte mais dúvidas do que a definição da raça de

29 MELLO, Celso Antonio Bandeira de. Curso de direito administrativo. 15. ed. São Paulo: Malheiros, 2002. p. 102. 
alguém, de modo que a motivação, nesse caso, deveria ser extensamente detalhada, para que fosse minudentemente escrutinada pelo juiz.

Se o Supremo Tribunal Federal tivesse apreciado melhor a questão da heteroidentificação quando teve oportunidade, na ADPF 186, talvez a situação hoje fosse mais clara. Não o fazendo, ao julgar a ação totalmente improcedente, o Tribunal liberou a UnB para adotar o critério que achasse melhor, autodeclaração ou heterorreconhecimento, sem especificar quais parâmetros fenotípicos fazem alguém ser negro no Brasil. Curiosamente, a própria UnB, ré da ação, não se aproveitou do resultado. Pouco depois do julgamento, o Congresso Nacional aprovou a Lei $\mathrm{n}^{\mathrm{o}}$ 12.711/2012, disciplinando que as ações afirmativas em Universidades Federais deveriam adotar o critério da autodeclaração. A lei foi seguida pelo Decreto nº 7.824/2012 e pela Portaria Normativa n⿳⺈ 18/2012, do Ministério da Educação, ambos reforçando o caráter autodeclarado da atribuição racial. Isso extinguiu a comissão da UnB e sua coirmã na UFPR. Mas a ausência de condenação expressa da heteroverificação racial permitiu que ela continue existindo, conforme demonstrado, na administração estadual, apoiada por decisões judiciais de outros tribunais.

\section{Cotas em concursos públicos federais: inconstitucionalidade formal}

Como se observa da análise anterior, a questão das ações afirmativas na forma de cotas estava longe de constituir um debate maduro no âmbito do ensino superior, quando foram implementadas as cotas em concursos públicos. Além do Paraná, cujos julgados já foram mencionados, e do Mato Grosso do Sul, que implantaram cotas em concursos públicos ainda na primeira década dos anos 2000, o estado do Rio de Janeiro o fez, em 2011, por intermédio da publicação do Decreto no 43.007/2011. A mobilização dos grupos sociais organizados fez com que essas políticas fossem adotadas também em alguns municípios. Contando com o apoio de uma jurisprudência, em regra, favorável, as cotas para o exercício de cargos públicos avançaram pelo Brasil, o que fez com que, no final de 2013, a presidente da República enviasse ao Congresso Nacional o Projeto de Lei no $6.738 / 2013$, convertido na Lei no $12.990 / 2014$, reservando aos autodeclarados negros, assim considerados os pretos e pardos, $20 \%$ das vagas nos concursos públicos federais.

Antes de adentrar o mérito do projeto federal, é preciso considerar seu aspecto formal, problema que se estende às demais políticas de cotas 
já implementadas. Há inconsistência acerca do instrumento normativo necessário para implementar as cotas em concursos públicos. No âmbito federal e nos estados do Paraná e do Mato Grosso do Sul, a criação se deu por lei. No município do Rio de Janeiro, por decreto do governador. Recentemente, a defensoria pública do estado de São Paulo anunciou a criação de cotas em seus próximos concursos para defensor e servidor, por intermédio de ato normativo interno, exarado por seu Conselho Superior, sem que exista, no estado, lei ou decreto nesse sentido. ${ }^{30} \mathrm{O}$ primeiro questionamento a ser formulado é de natureza formal: qual o instrumento normativo adequado para a criação de cotas em concursos públicos?

A análise precisa partir de uma questão fundamental, que é o instituto do concurso público. Ao contrário do exame vestibular, o concurso público é uma regra constitucional explícita, que ocupa local de destaque no inciso II do longo art. 37 da Constituição. Ali consta que o acesso aos cargos públicos “depende de aprovação prévia em concurso público de provas ou de provas e títulos, de acordo com a natureza e a complexidade do cargo ou emprego", ou seja, os requisitos para a investidura em um cargo público dependem unicamente de características do cargo, não de características do candidato. Se um cargo fosse mais bem exercido pelo fato de alguém ser negro, essa exigência certamente seria constitucional. ${ }^{31}$ Mas a Constituição parece não albergar a possibilidade de que o concurso público sirva a outras políticas públicas que não ao recrutamento dos mais capacitados para o exercício do cargo. O Supremo Tribunal Federal já fez essa afirmação, em inúmeras ocasiões, tendo a ministra Rosa Weber sumarizado: ${ }^{32}$

Destaco, à demasia, firme a jurisprudência desta Suprema Corte no sentido de que o acesso a cargos, empregos e funções públicas, pela via do concurso público, deve se dar de forma ampla, somente passível de restrições se a natureza das atribuições do cargo assim exigir, observados os princípios constitucionais da razoabilidade e da legalidade.

30 A notícia foi divulgada em <www.defensoria.sp.gov.br $>$ e, amplamente, na imprensa nacional.

31 Em outra ocasião, defendeu-se a possibilidade de restrição de concursos públicos aos índios, em razão de sua maior propensão ao bom exercício de determinadas funções. Ver VITORELLI, Edilson. Estatuto do índio. 2. ed. Salvador: Juspodivm, 2013.

32 ARE 795624, relator(a): min. Rosa Weber, julgado em 18/2/2014. 
De fato, em muitas ocasiões, o STF afirmou que as exigências para ingresso em cargo público devem estar estritamente relacionadas com o exercício do próprio cargo. Isso se deu, por exemplo, em relação a limite de idade, ${ }^{33}$ estatura $^{34}$ e aptidão física. ${ }^{35}$ Uma forma de contornar esses precedentes é afirmar que a reserva de $20 \%$ das vagas para negros não impõe a exigência de que o candidato seja negro, de modo que não se estaria impondo novo requisito para o exercício do cargo. Isso é uma meia verdade, já que a concorrência a essas vagas reservadas, mesmo que não às demais, exigiria uma condição não relacionada com o exercício do cargo.

Ainda que se aceite esse argumento como verdadeiro, ele não resolve o problema de que uma pessoa será beneficiada no certame por um atributo não inerente ao desenvolvimento futuro de suas funções. Nesse sentido, o STF tem inúmeros precedentes, em casos mais e menos caricaturais, inadmitindo a atribuição de vantagens de tal natureza. Por exemplo, o título de "Pioneiro do Tocantins" foi considerado apto a atribuir pontos em provas de concurso daquele estado, o que o Supremo Tribunal não admitiu. ${ }^{36}$ Mesmo a atribuição de pontos por experiência anterior no cargo, embora relacionada com o exercício da função, eis que indicativa de aptidão para o seu desempenho, foi vista com ressalvas pelo STF. ${ }^{37}$

Nesse quadro, é induvidoso que a admissão de que lei ordinária, ou mesmo ato infralegal, atribua vantagem competitiva a negros em concursos públicos constituiria um afastamento inaudito da jurisprudência atualmente consolidada no Supremo Tribunal. E nem se imagine que a analogia com a situação dos deficientes físicos traria algum alento em sentido contrário: o texto do art. 37, VIII é obra do legislador constituinte originário, que, como sabido, tudo pode. É difícil imaginar que a mesma liberdade de exceção seja

33 Súmula 683: “O limite de idade para a inscrição em concurso público só se legitima em face do art. 7º , XXX, da Constituição, quando possa ser justificado pela natureza das atribuições do cargo a ser preenchido".

34 AI 851.587-AgR, rel. min. Marco Aurélio, j. 19-6-2012.

35 AI 851.587-AgR, rel. min. Marco Aurélio, j. 19-6-2012, e RE 150.455, rel. min. Marco Aurélio, j. 15-12-1998.

36 Rcl 5.819, rel. min. Cármen Lúcia, julgamento em 20-5-2009.

37 "Discrepa da razoabilidade norteadora dos atos da administração pública o fato de o edital de concurso emprestar ao tempo de serviço público pontuação superior a títulos referentes a pós-graduação" (RE 205.535-AgR, rel. min. Marco Aurélio, julgamento em 22-5-1998, Segunda Turma, DJ de 14-8-1998.). No mesmo sentido, "Viola o princípio constitucional da isonomia norma que estabelece como título o mero exercício de função pública" (ADI 3.443, rel. min. Carlos Velloso, julgamento em 8-9-2005, Plenário, DJ de 23-9-2005). 
dada ao legislador ordinário ou a órgãos da administração, que sequer têm competência para inovar na ordem jurídica.

O problema, conforme percebem os autores de direito administrativo, é que a seleção de interessados de acordo com seu potencial para melhor desempenho do cargo público é inerente ao próprio conceito de concurso público. José dos Santos Carvalho Filho afirma: ${ }^{38}$

Concurso público é o procedimento administrativo que tem por fim aferir as aptidões pessoais e selecionar os melhores candidatos ao provimento dos cargos e funções públicas. Na aferição pessoal, o Estado verifica a capacidade intelectual, física e psíquica de interessados em ocupar funções públicas e no aspecto seletivo são escolhidos aqueles que ultrapassam as barreiras opostas no procedimento, obedecida sempre a ordem de classificação. Cuida-se, na verdade, do mais idôneo meio de recrutamento de servidores.

Assim, o conceito de concurso público, albergado pela Constituição, pressupõe que os candidatos serão avaliados única e exclusivamente em relação a sua aptidão para o exercício do cargo, com uma única exceção, prevista no texto originário da Carta, que são os deficientes físicos. Por essa razão, parece que a inserção de uma nova exceção na regra constitucional não pode ser deixada ao alvedrio do legislador ordinário, muito menos do administrador público, por mais nobres que sejam as razões e as intenções que os motivam. Seria necessária, no mínimo, Emenda Constitucional para excepcionar a regra do concurso público, isso para não tomar posição quanto à possível inconstitucionalidade mesmo desse instrumento, tendo em conta a substancial possibilidade de se sustentar, no contexto jurisprudencial atual, que o concurso é cláusula pétrea e não poderia sofrer restrições, nem mesmo decorrentes de Emendas. ${ }^{39}$

38 CARVALHO FILHO, José dos Santos. Manual de direito administrativo. 17. ed. Rio de Janeiro: Lumen Juris, 2007. p. 540.

39 Esse debate, que extravasa os limites do presente estudo, eis que desnecessário ao argumento aqui desenvolvido, é crucial em relação à discussão da Proposta de Emenda Constitucional no 471/2005, que pretende excluir determinados oficiais de cartórios extrajudiciais da exigência concursal. 


\section{Cotas em concursos públicos: inconstitucionalidade material}

A afirmação da inconstitucionalidade formal das normas que instituíram cotas para negros no recrutamento de servidores públicos, contida no tópico anterior, não significa que tenha havido má intenção por parte de seus patrocinadores. Mas ainda resta analisar se essas boas intenções, aplicadas especificamente ao contexto de recrutamento de servidores públicos, sustentam uma política pública valiosa. $\mathrm{O}$ problema aqui não é mais saber se existe preconceito racial, mas se o sistema adotado pela lei (ou pelos administradores) é apto a alcançar o fim que motiva a sua adoção. Isso é o que a doutrina e a jurisprudência norte-americana chamam de uma política "narrowly tailored", feita sob medida para a finalidade que se pretende alcançar. ${ }^{40}$ Em Grutter v. Bollinger, a Suprema Corte explicou essa exigência, nos seguintes termos:

Mesmo nas limitadas circunstâncias em que a utilização de distinções raciais é permissível para se atingir um interesse estatal, o governo ainda está constrangido, sob cláusula da igual proteção, na forma de agir para alcançar esse fim: os meios escolhidos para alcançar o propósito governamental afirmado devem ser específica e rigorosamente elaborados para alcançar tanto. ${ }^{41}$

Logo, o simples fato de uma norma visar a igualdade racial é insuficiente para que seja constitucional. É preciso que os meios adotados sejam compatíveis e proporcionais em relação ao fim.

\subsection{Inaplicabilidade dos precedentes norte-americanos}

Antes de se realizar a análise específica das cotas brasileiras, é preciso esclarecer que a jurisprudência ou a experiência norte-americana em ações afirmativas não socorre em nada o Brasil, no que se refere às cotas em concursos públicos. Em primeiro lugar, não existem políticas de cotas nos Estados

40 FARBER, Daniel et al. Constitutional law: cases and materials. 5. ed. St. Paul: West, 2013. Na jurisprudência da Suprema Corte, ver, por exemplo, Grutter v. Bollinger, 539 U.S. 306.

${ }^{41}$ Grutter v. Bollinger, julgado em 2003. 
Unidos e a Suprema Corte já afirmou expressamente que, se vierem a ser criadas, cotas serão inconstitucionais. Em Bakke v. Regents of the University of California, o primeiro caso em que a Suprema Corte decidiu pelo uso de critérios raciais para a admissão em universidades, ficou assentado que a raça não poderia ser um critério para a exclusão de candidatos ao programa universitário, mas poderia ser um dos critérios de admissão. O programa de ação afirmativa da Universidade da Califórnia foi julgado inconstitucional, tendo sobrevivido o de Harvard, a qual figurou na lide como amicus curiae. Harvard considerava, em uma "visão holística", todas as qualidades do candidato, inclusive a raça. Em 2003, nos casos Grutter v. Bollinger e Gratz v. Bollinger, a Suprema Corte reafirmou essa posição, não admitindo que um número determinado de vagas seja reservado a candidatos de determinada raça, nem que esse fator tenha um peso fixo, por exemplo, atribuindo um determinado número de pontos na avaliação do candidato, e nem que a Universidade tente fazer com que o perfil racial de seus ingressantes seja correspondente ao do total de candidatos ou ao da população em seu entorno. A única conduta admissível, ainda que por muitos criticada em razão de sua falta de transparência, é considerar a raça no meio de uma "massa crítica" de fatores, sem peso predeterminado, no processo de seleção.

Em relação a empregos, públicos ou privados, não existem cotas raciais nos Estados Unidos. O que se proíbe é que empregadores, de modo arbitrário, não admitam ou demitam negros, apenas em razão da raça, mas é necessário demonstrar que houve a intenção de praticar a conduta por motivo racial, não bastando, para tanto, o fato de uma empresa só ter empregados brancos. A teoria do impacto desproporcional (disparate impact doctrine) não dispensa essa demonstração. O objetivo da teoria é a análise de medidas, públicas ou privadas, aparentemente neutras do ponto de vista racial, mas cuja aplicação concreta acarreta, propositadamente ou não, prejuízo maior desproporcional - à minoria. Conforme ressalta Daniel Sarmento, ${ }^{42}$ não se trata, aqui, de discriminação de fato, ou seja, de mera aplicação distorcida de uma norma jurídica boa em si mesma. Se há discriminação de fato, a norma pode ser aplicada sem acarretar desigualdade. Na discriminação indireta, não há como aplicar a norma sem desfavorecer o grupo vulnerável.

42 SARMENTO, Daniel. Direito constitucional e igualdade étnico-racial. In: PIOVESAN, Flávia; MARTINS DE SOUZA, Douglas (Coord.). Ordem jurídica e igualdade étnico-racial. Rio de Janeiro: Lumen Juris, 2008. 
A teoria surge em 1964, no caso Griggs v. Duke Power Co., o qual tem um contexto fático bastante específico. A companhia ré prestava serviços na Carolina do Norte e, no período em que a segregação racial era lícita, contratava negros apenas para o seu departamento mais subordinado (labor department). Com a aprovação do Civil Rights Act, em 1964, essa conduta passou a ser ilícita. Literalmente, no dia seguinte à a provação do ato, a empresa passou a adotar um teste escrito para a admissão e promoção de empregados, além da exigência de diploma de ensino médio. Como os negros tinham, até então, estudado em escolas segregadas de pior qualidade, a aplicação dessa norma, aparentemente neutra, os atingia de modo muito mais grave, o que foi demonstrado estatisticamente.

Assim, esse precedente só se aplicaria ao Brasil se fosse possível demonstrar que as provas de concursos públicos, por alguma razão, favorecem a contratação de pessoas brancas, o que ninguém argumenta ocorrer. O Brasil nunca teve políticas de segregação racial oficiais e, com as cotas no ensino superior implantadas em algumas universidades públicas, há 10 anos, não há argumento para se dizer que os negros sejam, de alguma forma, excluídos do ensino público no país, de modo a serem prejudicados em um concurso. Em segundo lugar, mesmo que se acredite e se pretenda demonstrar esse ponto, é necessário que se faça um estudo estatístico sobre o perfil racial dos candidatos aos cargos públicos, em cada uma das carreiras, e o perfil dos aprovados, no intuito de se comprovar que a prova para aquele cargo, de alguma forma, impacta desproporcionalmente sobre os negros. Em terceiro lugar, para se adotar a lógica norte-americana, a forma para a solução desse problema seria a mudança da prova, identificando-se o elemento que a torna racialmente lesiva, e não a reserva de vagas.

Se não bastasse tudo isso, a aplicação da experiência norte-americana no Brasil ainda é obstada por um último problema: a teoria do impacto desproporcional foi abandonada pela Suprema Corte, ainda em 1976, no julgamento de Washington v. Davis. Passou-se a exigir, além do impacto desproporcional, que os interessados demonstrassem a existência de intento discriminatório por parte da instituição. ${ }^{43} \mathrm{O}$ caso era muito similar ao anterior, com candidatos ao cargo de bombeiro no Distrito de Columbia alegando que

43 Para uma discussão sobre os problemas e limites da teoria, ver RUTHRGLEN, George. Disparate impact, discrimination, and the essentially contested concept of equality. Fordham Law Review, v. 74, p. 2313-2338, 2006. 
um teste de recrutamento excluía desproporcionalmente os negros. Eles foram bem-sucedidos nas instâncias inferiores, mas a Suprema Corte afirmou que

nossas decisões anteriores não adotaram a proposição de que a lei ou outros atos oficiais, independentemente de refletirem um propósito discriminatório, são inconstitucionais apenas porque tenham um impacto desproporcional em relação a raça [...] Impacto desproporcional não é irrelevante, mas não é a única pedra de toque da discriminação racial proibida pela constituição. Sozinho, ele não determina a incidência da regra de que classificações raciais estão sujeitas ao escrutínio mais estrito e só são justificáveis pelas mais substanciais considerações.

Em 2009, julgando Ricci v. DeStefano, a Suprema Corte decidiu pela ilegalidade do ato do Corpo de Bombeiros de New Haven, que anulou um teste de promoção no qual nenhum negro foi classificado. $\mathrm{O}$ órgão argumentava que poderia ser responsabilizado pela aplicação de um teste que gerou impacto desproporcional. Além de dar razão aos bombeiros brancos, aprovados no teste, o caso ainda custou aos contribuintes locais US\$ 2 milhões em indenização aos aprovados, pelo atraso nas promoções, e US\$ 3 milhões em honorários e custas para sua advogada.

Assim, é preciso que fique claro que a experiência norte-americana não avaliza a intenção brasileira de criar cotas raciais em recrutamento de servidores públicos, pelo simples fato de que a maioria dos servidores públicos atualmente é branca. Não que isso proíba o Brasil de fazê-lo, mas deverá, para o bem ou para o mal, assumir seu pioneirismo, e não tentar apoiá-lo na experiência estrangeira.

\subsection{Cotas raciais em concursos públicos federais: inconstitucionalidade material}

Se não há experiência internacional, resta analisar como o Brasil criou, sozinho, esse novo caminho, bem como os fatores que foram levados em consideração. O Projeto de Lei n⿳ำ 6.738/13 não é a primeira tentativa do governo federal para implantar políticas raciais na administração pública. Desde 2002, existe o Decreto no 4.228, que determina a "observância, pelos órgãos da Administração Pública Federal, de requisito que garanta a realização de metas percentuais de participação de afrodescendentes, mulheres e pessoas 
portadoras de deficiência no preenchimento de cargos em comissão do GrupoDireção e Assessoramento Superiores - DAS". Essa disposição, entretanto, nunca foi implementada. Nenhum órgão da administração pública federal estabeleceu formalmente metas para o recrutamento de negros ou mulheres nos cargos de livre nomeação. Só há uma preferência para o recrutamento de negros, ainda assim, de modo informal, em cargos comissionados nas funções especificamente destinadas à gestão de políticas raciais, o que seria de se esperar. Nem mesmo os presidentes da República que inauguraram mandatos após a edição do Decreto o cumpriram para a escolha de seus próprios auxiliares diretos. Na fotografia oficial de posse do presidente Luiz Inácio Lula da Silva, em 2006, há apenas três negros: os ministros da Cultura, do Meio Ambiente e da Igualdade Racial, em um total de 34 autoridades, ou seja, menos de 10\%. Quatro anos depois, na inauguração do governo Dilma Rousseff, o número caiu para dois: os ministros do Esporte e da Igualdade Racial, e o primeiro veio a ser exonerado, meses depois, por suposto envolvimento em caso de corrupção, sendo substituído por um branco. Em 2015, entre 40 ministros constantes na fotografia de posse presidencial, apenas dois podem ser qualificados como negros.

Assim, o próprio presidente da República, signatário do Decreto no 4.228/2002, e sua sucessora não conseguiram cumpri-lo para o livre recrutamento de seus auxiliares diretos. Apesar disso, antes de serem adotadas medidas para corrigir essa omissão, ou, pelo menos, de se determinar a elaboração de um diagnóstico relativo a suas causas, foi enviado ao Congresso Nacional projeto de lei com o objetivo de estender a política aos cargos efetivos. $^{44}$

Em segundo lugar, mesmo que o Decreto já existisse há tantos anos, o Projeto de Lei no 6.738/2013 foi enviado ao Congresso Nacional em 7 de novembro de 2013, com pedido de urgência na tramitação, nos termos do art. 64 da Constituição. Embora o genérico dispositivo constitucional permita que o presidente da República solicite urgência para seus projetos, em qualquer caso, é de se imaginar qual seria a urgência na espécie. O mandato presidencial vigente já estava em curso há praticamente três anos, o Estatuto da Igualdade Racial vigora desde julho de 2010 e o Decreto no 4.228/2002 já

44 Além do Decreto no 4.228/2002, o Instituto Rio Branco também reserva, há anos, vagas na carreira diplomática para negros. Mas a situação do Rio Branco é um pouco diversa, porque o certame do Instituto é um misto de vestibular e concurso público, já que existe um curso de formação prolongado antes do exercício da função. Além disso, a cota prevista é apenas para habilitação à segunda etapa do concurso, não havendo garantia de posicionamento final. 
havia completado 11 anos nesta data. Mesmo os dados estatísticos citados na mensagem de encaminhamento do projeto, que serão analisados a seguir, são relativos ao censo de 2010, ou seja, já estavam disponíveis há algum tempo quando o envio ocorreu.

Não que essa falsa urgência implique inconstitucionalidade, mas é preciso reconhecer que se trata de assunto altamente não recomendado para discussão de afogadilho. Relações raciais são questões complexas e, sendo certo que não há acordo sobre elas, é saudável que o Congresso Nacional as discuta amplamente. O histórico de tramitação do projeto na Câmara dos Deputados mostra que não foi convocada uma audiência pública sequer, para propiciar a ampliação dos debates. Toda a tramitação na casa durou apenas quatro meses, isso sem descontar o recesso legislativo no final do ano de 2013. No Senado, o projeto, já aprovado pela Câmara dos Deputados, foi recebido em $1^{\circ}$ de abril de 2014 e aprovado em 20 de maio, também sem a realização de qualquer debate público de maior alcance que o da tramitação ordinária de uma lei. A restrição ao debate de questões polêmicas é reprovável em uma democracia, independentemente do mérito do projeto apresentado.

Quanto a sua constitucionalidade, em termos de mérito, há não menos que 11 razões para sustentá-la. A primeira delas é oriunda dos motivos citados para a aprovação do projeto, em sua mensagem de encaminhamento. Segundo o documento, entre os servidores que possuem informação de raça no sistema do Poder Executivo Federal, 30\% são negros, enquanto a população negra nacional equivale a 50,74\%. Contudo, mesmo que se admita que os dados apresentados são corretos, a diferença estatística não é suficiente para embasar a proposta, porque não foi considerado o tempo de exercício no cargo desses servidores, de modo que é impossível saber qual a tendência atual do recrutamento, em termos de raça. Pode ser que, nos últimos tempos, o número de negros venha crescendo, até mesmo em razão das cotas nas universidades, e a tendência seja que a solução venha com o tempo, sem necessidade de cotas. A divergência estatística, mal qualificada, não sustenta a solução proposta para a adoção do sistema.

Em segundo lugar, não há informação quanto ao perfil racial dos candidatos aos concursos públicos federais. Como se sabe, prestar concurso público, atualmente, no Brasil, é algo financeiramente dispendioso e exige do candidato grande preparação intelectual e tempo de estudo, para que tenha mínimas condições de ser aprovado. $\mathrm{O}$ dado a ser investigado, quando se quer justificar a disparidade racial, não é o universo populacional nacional, mas o universo dos candidatos a cargos públicos federais. Não há evidências 
de que o perfil racial desse grupo seja idêntico ao da população nacional. Pelo contrário, como a maioria da população pobre no Brasil é negra, é provável que o perfil racial dos candidatos a cargos públicos federais seja consideravelmente diferente do perfil geral dos brasileiros. A comparação estatística, nos termos em que exposta na mensagem presidencial, não faz sentido. Ainda que se pretenda afirmar que a disparidade a ser corrigida é o baixo número de negros candidatos aos cargos, o problema não estaria no concurso público, mas na formação dos candidatos, em termos educacionais e sociais. Logo, as ações afirmativas deveriam ser adotadas em outros níveis, como no acesso às universidades, não com a reserva de vagas em cargos públicos.

Terceiro, mesmo que se comprovasse que o perfil racial das pessoas que se candidatam a cargos públicos federais é diferente do perfil racial dos quadros do serviço público federal e que, de modo geral, os concursos atuais estão mantendo essa tendência, para favorecer a predominância de servidores brancos, ainda seria necessário segmentar a comparação em relação ao nível do cargo ocupado pelo servidor e à respectiva carreira. Isso se deve ao fato de que, como os mais pobres são negros, é provável que fiquem concentrados nos cargos subordinados, enquanto as carreiras mais elevadas permanecem "embranquecidas", mormente quando se considera que os concursos para cargos mais bem remunerados, por exemplo, na área jurídica, costumam ser mais limitados pela nota de corte mínima do que pelo número de vagas. Uma política que desconsidere as peculiaridades das diferentes carreiras e de seus respectivos concursos favorece o posicionamento dos negros apenas em cargos subalternos.

Quarto, o perfil racial citado pela justificativa leva em consideração tanto os cargos efetivos quanto os cargos comissionados, já que extraiu dados de todos os servidores que possuíam, na data de sua elaboração, informação de raça no sistema de administração de pessoal. Isso significa que o fracasso do Poder Executivo em implantar, depois de 11 anos, a determinação do Decreto no 4.228/2002 é parte da justificativa pela qual se pretendeu estabelecer a política para os cargos efetivos. Se o Poder Executivo tivesse cumprido, nos cargos de livre nomeação, a mesma reserva de vagas que se implementa para os cargos efetivos, a disparidade estatística entre o perfil racial da administração e da população brasileira certamente seria menor.

Quinto, ainda que nenhum dos motivos anteriores seja aceito, não há demonstração de que o quantitativo de vagas cuja reserva se determinou é devidamente ajustado aos fins que pretende. O percentual estabelecido $(20 \%$, 
durante os 10 anos de vigência da lei) não é justificado na mensagem, nem por qualquer estudo produzido pelo governo federal. Trata-se, ao que parece, de percentual aleatório, sendo impossível prever, ao final de 10 anos, seus efeitos em relação à disparidade entre o perfil racial do serviço público federal e o da população nacional.

Sexto, no julgamento da ADPF 186, alguns ministros do Supremo Tribunal Federal demonstraram desconforto com a ideia de se criar políticas de ações afirmativas com corte exclusivamente racial, sem levar em conta o nível socioeconômico dos candidatos. Essa ideia figurou apenas em obter dicta, porque a ação foi julgada totalmente improcedente. O legislador federal, todavia, foi sensível a ela e, na criação das cotas em universidades federais, por intermédio da Lei no $12.711 / 2012$, estabeleceu cotas raciais que pressupõem um corte social. O candidato só pode ser beneficiado pelo fato de ser negro se tiver estudado, por toda a sua vida, em escola pública, o que é um indicativo de que teve acesso a um ensino de menor qualidade, presumidamente por falta de condições financeiras. A Lei no $12.711 / 2012$ resolveu boa parte dos dilemas das cotas no ensino superior. Em contradição, a Lei no $12.990 / 2014$ abandonou esse avanço e criou cotas raciais sem qualquer corte social. Como o número de vagas reservadas é pequeno e o nível de concorrência é alto, é possível afirmar que a Lei no 12.990/2014 beneficiará apenas os negros de classe média e alta, que já constituem parcela privilegiada dentro do grupo. Apenas eles terão condições financeiras para se preparar com o nível de rigor atualmente necessário para a aprovação em um cargo público federal. ${ }^{45}$ Os negros pobres provavelmente nada terão a ganhar com as cotas estabelecidas, de modo que elas não são aptas a gerar maior igualdade social.

Sétimo, a mensagem de justificativa da Presidência da República, em seu item 5, introduz o argumento de que o objetivo da política de cotas

45 Observação nesse sentido foi feita pelo Tribunal de Justiça do Espírito Santo, ao julgar inconstitucional a Lei $\mathrm{n}^{\mathrm{o}}$ 6.225/2004, do município de Vitória. O desembargador Arnaldo Santos Souza entendeu que "não é a tonalidade da pele que impossibilita os afrodescendentes de ingressarem no serviço público municipal, mas sim a precária situação econômica. Eu não vejo motivos para aceitar as cotas no serviço público". Além disso, mencionou o problema da ausência de um critério social: "Na medida em que institui a consciência estatal da raça, a reserva de vagas promove a ofensa arbitrária ao princípio da igualdade, gerando discriminação reversa em relação aos brancos pobres, além de favorecer a classe média negra, que não seria a mais carente dos benefícios estatais". Por fim, o desembargador Álvaro Manoel Rosindo Bourguignon manifestou preocupação com o âmbito de aplicabilidade da norma: "A afrodescendência se dá pela cor da pele? Quem serão os privilegiados?". A notícia do julgamento está em: <www.tj.es.gov.br/portal/\%C3\%9Altimas-Not\%C3\%ADcias/tjes-declarainconstitucional-lei-de-cotas-para-afrodescendentes-en-concursos-publicos.html>. 
seria promover a "diversidade" na administração pública. Diversidade é um conceito indeterminado, que apenas mascara a discussão subjacente, que é a questão racial. Ele é o fundamento mais utilizado nos Estados Unidos e, provavelmente, daí veio a inspiração para os redatores brasileiros. Nos julgados relativos às ações afirmativas americanas, a Suprema Corte asseverou, reiteradamente, que o único objetivo constitucionalmente aceitável para implementá-las é a promoção da diversidade nas universidades. Universidades são centros de produção de conhecimento, de modo que, quanto mais variadas forem as experiências de vida de seus membros, potencialmente mais rica será essa produção. Todavia, a trasladação dessa justificativa para o contexto da administração pública, coisa que não existe nos Estados Unidos, demandaria definir de que diversidade se trata, qual o seu conteúdo e qual objetivo constitucional se espera seja com ela alcançado. Além disso, mesmo nos Estados Unidos, diversos autores contestam a possibilidade de que qualquer tipo de diversidade seja obtido apenas em decorrência da raça de uma pessoa. Pertencer a um grupo racial não significa, necessariamente, ter experiência racial ou ter experimentado racismo, ou ser engajado em causas raciais. Dizer que todo negro tem um tipo de dever de servir de instrumento de promoção da diversidade é, em si, uma construção racista, já que estereotipa o indivíduo em função de características externas. Mais que isso, diversidade é uma questão qualitativa, não quantitativa. Se a administração pública federal não tivesse um único negro, é possível que a introdução das cotas pudesse justificar esse efeito. Todavia, quando o governo federal admite que 30\% dos servidores públicos federais atuais são negros, é altamente improvável que a elevação desse percentual para o mesmo patamar da população, 50\%, seja capaz de promover qualquer diversidade adicional, mesmo que se consiga definir o conteúdo desse elemento.

Oitavo, o faixo de luz estatístico que a Presidência da República deitou sobre a administração pública federal é aleatório. Por qual razão foi analisada apenas a disparidade entre negros e brancos no serviço público? Por que não entre mulheres e homens? Ou entre habitantes do Norte e do Nordeste e habitantes do Sul e do Sudeste do país? Segundo o Boletim Estatístico de Pessoal e Informações Organizacionais, divulgado pelo Ministério do Planejamento, a administração pública federal contava, em outubro de 2014, com 308.540 homens e 261.526 mulheres, em um total de 570.066 servidores. Isso significa que o serviço público federal brasileiro é composto de 54,1\% de homens e $45,9 \%$ de mulheres, enquanto a população brasileira tem 51\% de mulheres e $49 \%$ de homens, segundo o IBGE. Na Presidência da República, ainda 
segundo o mesmo documento, o número de homens corresponde a $68,2 \%$ e, no Ministério da Justiça, atinge impressionantes 78,6\%. Isso significa que, da mesma forma que existe uma disparidade entre brancos e negros, existe uma disparidade entre homens e mulheres. Não há dados estatísticos sobre a região de origem dos servidores, entretanto, como as regiões Sul e Sudeste são as mais ricas e, conforme mencionado, se candidatar a um concurso público exige dinheiro, é muito provável que habitantes do Norte e do Nordeste estejam sub-representados na administração pública federal, em relação ao contingente populacional. ${ }^{46}$ Assim, outras desigualdades, igualmente verificáveis, quando se parte do pressuposto equivocado da comparação da força de trabalho administrativa federal com a população nacional, foram deixadas de lado.

Nono, assim como o Estatuto da Igualdade Racial, a Lei no 12.990/2014 abandonou as outras minorias, tanto étnicas quanto não étnicas. Os índios, segundo o IBGE, não são negros, mas constituem outra categoria à parte, como percebeu o legislador sul-mato-grossense, que, na Lei estadual $\mathrm{n}^{\mathrm{o}}$ 14.274/2003, estabeleceu cotas para negros e índios, ao contrário do legislador federal. Assim, um índio que se declare negro, para participar de um concurso público, estará fazendo declaração falsa e deverá ser eliminado. Também foram esquecidas as minorias étnicas não negras e os grupos tradicionais, como os ciganos, ribeirinhos, faxinais, quebradeiras de coco etc. Igualmente ignorados foram os homossexuais. Da perspectiva da promoção da diversidade e da afirmação da identidade do grupo, privilegiar os homossexuais seria facilmente justificável, já que esse grupo sofre, presentemente, preconceito tão ou mais aberto e ofensivo que o dirigido aos negros. Basta, para essa constatação, perder-se meia hora diante de algum dos programas de comédia cotidiana e livremente exibidos na televisão brasileira.

Décimo, a solução para o não recrutamento de negros na administração pública não pode ser, simplesmente, contratar servidores públicos menos qualificados. O Brasil presume, mesmo que isso possa não ser verdadeiro em todos os casos, que o concurso público é o mecanismo adequado para selecionar os servidores mais capacitados para o exercício da função. Salvo para os deficientes físicos, por disposição originária do texto constitucional, a única política pública que se faz com concursos públicos é a de fornecer ao cidadão brasileiro um serviço público de qualidade. Isso se dá com a

46 MINISTÉRIO DO PLANEJAMENTO, ORÇAMENTO E GESTÃO. Boletim Estatístico de Pessoal e Informações Organizacionais, Brasília, v. 19, n. 222, 2014. 
contratação dos interessados que mostram ser mais aptos ao desempenho da função, por intermédio de avaliação de provas e títulos. Não se faz distribuição de renda, ou igualdade racial, ou quaisquer outras políticas públicas, por mais meritórias que sejam, à custa da possível redução da qualidade do serviço prestado ao cidadão que o remunera.

Por fim, permanece o problema de se definir quem é negro. A Lei no 12.990/2014 pretende estender seus benefícios a pretos e pardos. O dado estatístico citado na mensagem de encaminhamento, ao fazer menção a 50,74\% da população brasileira ser negra, está levando em conta os dois grupos. Logo, é ilícito que os pardos sejam excluídos de sua incidência, embora tanto a lei quanto a jurisprudência tenham se recusado a estabelecer critérios para definir quando alguém deixa de ser pardo e passa a ser branco. Para fugir do problema, a lei estabelece como parâmetro de definição a autodeclaração, mas, ao mesmo tempo, afirma que o indivíduo pode ser eliminado do concurso ou ter seu ato de nomeação anulado se sua declaração for "falsa". Mas como poderá ser falsa, se é uma "autodeclaração"? Como a má-fé não se presume, a não ser que a administração possa produzir prova, testemunhal ou documental, que ateste que o candidato se representava como branco, mas, apenas para fraudar o concurso, se declarou negro, é impossível provar a falsidade.

O argumento da possibilidade de se punir a declaração falsa justificou, no Paraná, a criação de comissões para a verificação das declarações, à revelia da lei e mesmo dos editais de concurso. A pesquisa jurisprudencial demonstra que a experiência vem sendo negativa. Os juízes, constrangidos pelo debate racial, preferem apelar para considerações processuais e para a ausência de prerrogativa de revisão dos atos administrativos, em descompasso com todo o restante da jurisprudência relativa a concursos públicos, deixando, assim, os candidatos ao alvedrio da administração. Na rara ocasião em que um desembargador resolveu entrar no mérito do litígio, discordou da avaliação da comissão e afirmou que, tendo visto a foto do candidato, o considerava negro. Nem seus critérios, nem os da malsinada comissão, foram expostos à crítica pública.

À vista de tudo isso, o absurdo começa a parecer plausível. É possível que os órgãos públicos federais adotem a mesma posição do Paraná e, mesmo sem previsão legal, comecem a criar comissões para avaliar a raça dos candidatos. Nesse caso, talvez seja melhor que o governo federal institua um tribunal racial, uma autoridade central, no Ministério do Planejamento, encarregada de verificar, em todos os casos, denúncias de falsas declarações raciais, ao 
invés de deixar essa definição para comissões ad hoc, a serem compostas por amadores, em cada concurso público, com o risco da adoção de critérios díspares. É claro que o nome, em um país com gosto por eufemismos, não poderia ser "tribunal racial", mas, certamente, não faltariam alternativas. Assim se teria um critério unívoco para definir quem é negro em toda a administração pública federal, e seria possível incumbir autoridades de notório saber na matéria de tal avaliação. Quem sabe, no futuro, se formaria uma "jurisprudência", que poderia orientar os candidatos a saber se estão se autodeclarando de modo verdadeiro ou falso. Quanto mais essa ideia parecer plausível, mais sombrio será o caminho pelo qual, sozinhos no mundo, a nação e o direito brasileiro caminham.

Em síntese, há diversos motivos para concluir que a Lei oㅜ 12.990/2014 é inconstitucional do ponto de vista material, por violar o princípio da igualdade e a regra constitucional que exige o concurso público para provimento dos cargos (art. 37, II, da Constituição), além do princípio constitucional da motivação dos atos administrativos, eis que a administração não explicita os fatores pelos quais entende que alguém é ou não é negro. Principalmente, a inconstitucionalidade decorre do fato de que o remédio desenhado pela lei para um problema, que é real, não se relaciona com as suas causas e nem com os elementos estatísticos que o fundamentam.

\section{Conclusão}

Ainda é difícil imaginar o que o Supremo Tribunal Federal decidirá, quando for confrontado com a difícil questão de reserva de vagas em concursos públicos para negros, seja na esfera federal, seja no âmbito dos estados. Em decisão monocrática, a ministra Carmen Lúcia afastou a aplicação da ADPF 186 como precedente nesses casos, embora, na espécie, o fundamento principal da decisão não tenha solucionado as dúvidas aqui apresentadas: ${ }^{47}$

Inicialmente, há que se ter em vista que o caso em exame é diverso daquele submetido à apreciação do Supremo Tribunal Federal, por meio da Arguição de Descumprimento de Preceito Fundamental (ADPF) 186, ajuizada na Corte pelo Partido Democratas (DEM). Na citada actio

47 Rcl 17585, relator(a): min. Cármen Lúcia, julgado em 11/6/2014, DJ 16/6/2014. 
o Plenário do STF considerou constitucional a política de cotas étnicoraciais para seleção de estudantes em determinada Universidade, o que diverge da pretensão inicial, cuja ação afirmativa está direcionada à reserva de vagas em concursos públicos municipais.

A conclusão deste trabalho aponta que, tanto em termos formais quanto em termos materiais, a constitucionalidade das cotas raciais é discutível. O concurso público é norma constitucional de grande valor para a evolução jurídica brasileira. José dos Santos Carvalho Filho afirma que "o concurso público é o instrumento que melhor representa o sistema do mérito, porque traduz um certame de que todos podem participar nas mesmas condições, permitindo que sejam escolhidos realmente os melhores candidatos" . ${ }^{48}$ Logo, permitir que concursos públicos sejam orientados por sistemas distintos do mérito, no Estado brasileiro, significa mudar a própria definição de tais certames. Nesse sentido, decidiu o Superior Tribunal de Justiça:

A promulgação da Constituição Federal de 1988 trouxe novos ideais à sociedade brasileira, dentre eles o axioma de que todos são iguais perante a lei, insculpido no art. 5o do texto maior como cláusula imodificável.

O preceito fundamental da igualdade exprime o consectário da exigência de concurso público para seleção dos melhores candidatos ao ingresso nos quadros da Administração Pública Direta e Indireta em todos os níveis governamentais, à luz da legalidade, impessoalidade, moralidade, publicidade e eficiência (caput do art. 37 da Constituição), que devem ser simultaneamente conjugados em concomitância com os incisos I e II do aludido dispositivo. [RMS 28041/GO, rel. min. Gilson Dipp, j. 25.5.2009]

Não parece que essa seja uma conquista da qual o Brasil deva abdicar. Não foi fácil o caminho da administração pública brasileira, para estabelecer um sistema de recrutamento que livrasse o país dos muitos vícios que o acompanharam ao longo da história. Durante a Assembleia Nacional Constituinte, o deputado Adolfo Oliveira afirmou que "[...] em relação a esse particular, a Constituição caminhou muito. A Constituição consagrou

48 Carvalho Filho, Manual de direito administrativo, op. cit., p. 541. 
o princípio do concurso público e a Constituição permite que na legislação ordinária façamos uma legislação realmente à altura do que se espera". É pouco provável que a pretensão constitucional fosse que o legislador inferior ou mesmo órgãos da administração pública se arvorassem da autoridade de excepcionar a norma constitucional, pelos motivos que julgassem válidos.

Aceitar a constitucionalidade das cotas para negros em concursos públicos é aceitar que, no futuro, o legislador está autorizado a criar outras exceções à norma constitucional, com embasamentos estatísticos que, conforme demonstrado ao longo do texto, são inconsistentes. Podemos, em alguns anos, ter cotas em razão do local de nascimento, de gênero, de orientação sexual etc. Em uma sociedade plural, haverá sempre uma minoria discreta e insular, para utilizar a expressão consagrada por John Hart Ely. Pretender solucionar esse problema com a criação de cotas ou de outros tipos de benefícios individuais diretamente apropriáveis pelos beneficiários redundará em um círculo infinito cujo único resultado concreto será o descrédito de um instituto constitucional de elevado valor. ${ }^{49}$

Em uma recente série ficcional televisiva sobre publicidade, a personagem se refere ao fato de que há uma única base para se vender uma ideia: felicidade. "Felicidade é um anúncio na beira da estrada que grita, reconfortantemente, que, o que quer que você esteja fazendo, você está certo". Seria mais popular, talvez mais "moderno", se o presente trabalho concluísse que tanto o legislador quanto os administradores e os brasileiros estão na vanguarda da igualdade racial no mundo e que, o que quer que eles estejam fazendo em favor dos negros, eles estão certos. Infelizmente, a atividade científica exige que as evidências sejam verificadas com frieza, mesmo por quem se dedica à causa da proteção das minorias. ${ }^{50} \mathrm{~A}$ análise aqui conduzida demonstra que as cotas raciais em concurso público não são a solução para o problema racial brasileiro, se fundam em achados estatísticos e premissas discutíveis, excluem outras minorias tão ou mais insulares e socialmente maltratadas que os negros e, acima de tudo, tergiversam com uma valiosa regra constitucional, reabrindo uma porta que o Constituinte de 1988 se esforçou para fechar. São, por isso, formal e materialmente inconstitucionais as leis e os atos normativos

49 ELY, John Hart. Democracy and distrust: a theory of judicial review. Cambridge: Harvard University Press, 1981.

50 Ver VITORELLI, Edilson. Estatuto do índio, op cit., e VITORELLI, Edilson. Estatuto da igualdade racial e comunidades quilombolas. Op cit. 
inferiores que estabelecem privilégios competitivos para candidatos em concursos públicos, não relacionados com o exercício futuro do cargo.

\section{Referências}

BARBUJANI, Guido. A invenção das raças. São Paulo: Contexto, 2007.

CARVALHO FILHO, José dos Santos. Manual de direito administrativo. 17. ed. Rio de Janeiro: Lumen Juris, 2007.

COULANGES, Fustel de. A cidade antiga. São Paulo: Martin Claret, 2002.

COLLIER, Peter; HOROWITZ, David. The Race Card: white guilt, black resentment, and the assault on Truth and Justice. Rocklin: Prima Publishing, 1997.

CRUZ, Levy. Democracia racial, uma hipótese. Disponível em: <www.fundaj. gov.br/tpd/128.html>. Acesso em: 15 ago. 2011.

GOMES, Joaquim Barbosa. Ação afirmativa e princípio constitucional da igualdade. Rio de Janeiro: Renovar, 2001.

ELY, John Hart. Democracy and distrust: a theory of judicial review. Cambridge: Harvard University Press, 1981.

FARBER, Daniel et al. Constitutional law: cases and materials. 5. ed. St. Paul: West, 2013.

GUIMARÃES, Antonio Sérgio Alfredo. Democracia racial. Disponível em: <www.fflch.usp.br/sociologia/as ag/Democracia\%20racial.pdf $>$. Acesso em: 15 ago. 2011.

HASENBALG, Carlos. Discriminação e desigualdades raciais no Brasil. 2. ed. Belo Horizonte: Editora UFMG; Rio de Janeiro: Iuperj, 2005.

HILL, Anita. Speaking truth to power. Nova York: Anchor Books, 1997.

IKAWA, Daniela. Ações afirmativas em universidades. Rio de Janeiro: Lumen Juris, 2008.

MELLO, Celso Antônio Bandeira de. Curso de direito administrativo. 15. ed. São Paulo: Malheiros, 2002.

. O conteúdo jurídico do princípio da igualdade. São Paulo: Malheiros, 2010. 
MINISTÉRIO DO PLANEJAMENTO, ORÇAMENTO E GESTÃO. Boletim Estatístico de Pessoal e Informações Organizacionais, Brasília, v. 19, n. 222, 2014.

NUNES, António José Avelãs; SCAFF, Fernando Facury. Os tribunais e o direito à saúde. Porto Alegre: Livraria do Advogado, 2011.

RIBEIRO, Carlos Antonio Costa. Classe, raça e mobilidade social. Dados Revista de Ciências Sociais, Rio de Janeiro, v. 49, n. 4, p. 833-876, 2006.

RUTHRGLEN, George. Disparate impact, discrimination, and the essentially contested concept of equality. Fordham Law Review, v. 74, p. 2313-2338, 2006.

SARMENTO, Daniel. Direito constitucional e igualdade étnico-racial. In: PIOVESAN, Flávia; MARTINS DE SOUZA, Douglas. Ordem jurídica e igualdade étnico-racial. Rio de Janeiro: Lumen Juris, 2008. p. 59-108.

VITORELLI, Edilson. Estatuto da igualdade racial e comunidades quilombolas. Salvador: Juspodivm, 2012. . Estatuto do índio. 2. ed. Salvador: Juspodivm, 2013. 